\title{
Crambe (Crambe abyssinica) Cultivation under Different Levels of Fertilization with Nitrogen, Phosphorus and Potassium
}

\author{
Ana Carolina F. de Vasconcelos ${ }^{1}$, Lúcia Helena G. Chaves ${ }^{1 *}$, Josely Dantas Fernandes ${ }^{2}$, \\ Gilvanise Alves Tito ${ }^{1}$ \\ ${ }^{1}$ Department of Agricultural Engineering, Federal University of Campina Grande, Paraiba State, Brazil \\ ${ }^{2}$ Department of Agroecology and Agropecuaria, State University of Paraiba, Paraiba State, Brazil \\ Email: *lhgarofalo@hotmail.com
}

How to cite this paper: de Vasconcelos, A.C.F., Chaves, L.H.G., Fernandes, J.D. and Tito, G.A. (2017) Crambe (Crambe abyssinica) Cultivation under Different Levels of Fertilization with Nitrogen, Phosphorus and Potassium. American Journal of Plant Sciences, 8, 2031-2039.

https://doi.org/10.4236/ajps.2017.89136

Received: July 3, 2017

Accepted: August 1, 2017

Published: August 4, 2017

Copyright $\odot 2017$ by authors and Scientific Research Publishing Inc. This work is licensed under the Creative Commons Attribution International License (CC BY 4.0).

http://creativecommons.org/licenses/by/4.0/

\begin{abstract}
The effects of fertilization on crambe are poorly understood; in this sense, this study aimed to evaluate the crambe growth under different levels of nitrogen $\left(0,40,80,120 \mathrm{~kg} \cdot \mathrm{ha}^{-1}\right)$, phosphorus $\left(0,50,100,150 \mathrm{~kg} \cdot \mathrm{ha}^{-1}\right)$, and potassium $\left(0,30,60,90 \mathrm{~kg} \cdot \mathrm{ha}^{-1}\right)$ in a greenhouse. The height of the plants, the production of dried biomass and that of 1000 grains of crambe were evaluated. The height of the plants was impaired as a function of increasing doses of nitrogen. The interaction of nitrogen and phosphorus in the crambe crop increased the number of grains and dry shoot biomass. The growth and yield of the crop were not influenced by the use of potassium in mineral fertilization.
\end{abstract}

\section{Keywords}

Biodiesel, Semiarid Region, Mineral Fertilization, Crambe Growth

\section{Introduction}

Crambe (Crambe abyssinica) is an oleaginous species of the Brassicaceae family, and presents about thirty species. The plant has a penetrating root that can reach depths greater than $15 \mathrm{~cm}$ which allows the plant to be relatively resistant to drought. However, water stress occurring during flowering or seed formation can cause losses. This crop is sensitive to temperatures below zero in planting and flowering [1].

In Brazil, research with crambe crop began in 1995 at the Mato Grosso do Sul Foundation, aiming to evaluate its behavior in the formation of soil cover [2]. However, with the advent of biodiesel production, this oleaginous crop became a 
very interesting option because of its advantages such as precocity, drought tolerance [3] and frost, low production costs, and productivity between 1000 and $1500 \mathrm{~kg} \cdot \mathrm{ha}^{-1}$, as well as higher oil production compared to other oil crops. In addition, crambe does not compete with crops for food production, making it viable to grow biofuels [4].

Oil extracted from crambe seeds contains $50 \%$ - 60\% erucic acid, which is a long chain fatty acid used as an industrial lubricant, corrosion inhibitor, and an ingredient in the manufacture of synthetic rubber, paints, plastic films, plasticizers, glues, adhesives and electrical insulation, among others [5].

Mineral nutrients have essential and specific functions in plant metabolism. If any nutrient is not present in satisfactory conditions to the plant, its deficiency generates anomalies due to changes in metabolism. Phosphorus, for example, among several functions, stimulates root development and flowering, accelerates physiological maturation, helps seed formation and increases productivity. In the same way, potassium is an important macronutrient, mainly for the synthesis of proteins and carbohydrates, for the production of photo assimilates for the grains, controls the water in the plant and for the process of opening and closing the stomata, regulates the assimilation of $\mathrm{CO}_{2}$, stimulates vegetative growth, and acts on ionic balance [6] [7]. Nitrogen is required by plants in quantities greater than any other mineral element, and the unavailability of this nutrient usually limits plant productivity in many natural and agricultural ecosystems. In addition, the level of $\mathrm{N}$ in the plant influences the absorption or distribution of practically all nutrients. Therefore, the deficiency of this element is characterized by the low growth rate, small plants, small leaves, premature death of older leaves, roots without branches, collapse and development of chloroplasts, chlorotic leaves with necrosis in the most advanced stage of the deficiency [6] [7].

Similar to other higher plants, crambe needs macro and micronutrients both found in soil due to natural fertility and incorporated by fertilizers and correctives. Therefore, the soils for planting must be fertile and with $\mathrm{pH}$ above 5.8. However, there are still no specific recommendations on the level of fertilization that is feasible for the crop [2], since many studies have reported different trends in the response of crambe to mineral fertilization [3] [5] [8].

In this sense, the objective of this study was to evaluate the development of crambe plants under mineral fertilization, related to the macronutrients nitrogen, phosphorus and potassium, aiming to potentiate this crop as a bioenergetic matrix for the semiarid and sub humid regions of Northeast Brazilian, bringing an alternative crop for smallholders in these regions during the rainfall shortage periods.

\section{Material and Methods}

\subsection{Experimental Site and Soil}

The experiment was installed and conducted in a greenhouse located at Campina

Grande Federal University (UFCG) in Campina Grande, PB, under the following 
geographical coordinates: $7^{\circ} 13^{\prime} 11^{\prime \prime S}$ and $35^{\circ} 52^{\prime} 31^{\prime \prime} \mathrm{W}$ and $550 \mathrm{~m}$ altitude. The soil samples were collected in the surface layer and, after being air-dried, were sieved and characterized for chemical and physical aspects [9]. The results are shown in Table 1.

As the crambe presents limitation to the root growth in soils with $\mathrm{pH}$ below 6.0 [2], the soil acidity was neutralized with the application of limestone. Then, the soil was incubated until its $\mathrm{pH}$ reached around 6.0 (approximately 50 days), ideal for the development of crambe. Subsequently, the soil was fertilized according to the previously established treatments.

\subsection{Design and Treatments}

The experiment followed a completely randomized experimental design in a $4 \times$ $4 \times 4$ factorial scheme, consisting of four nitrogen doses $(0,40,80,120 \mathrm{~kg} \mathrm{~N}$ $\left.\mathrm{ha}^{-1}\right)$, four doses of phosphorus $\left(0,50,100,150 \mathrm{~kg} \mathrm{P}_{2} \mathrm{O}_{5} \mathrm{ha}^{-1}\right)$, and four doses of potassium $\left(0 ; 30 ; 60 ; 90 \mathrm{~kg} \mathrm{~K}_{2} \mathrm{O} \mathrm{ha}^{-1}\right)$, with three replicates, totaling 144 experimental units. The doses of $\mathrm{N}$ and $\mathrm{K}_{2} \mathrm{O}$ were supplied by means of the fertilizers urea $(46 \% \mathrm{~N})$ and potassium chloride $\left(60 \% \mathrm{~K}_{2} \mathrm{O}\right)$, respectively, whereas the $\mathrm{P}_{2} \mathrm{O}_{5}$ dose was supplied by simple superphosphate $\left(18 \% \mathrm{P}_{2} \mathrm{O}_{5}\right)$.

\subsection{Plant Sampling and Measurements}

Each experimental unit consisted of a pot with $8 \mathrm{~kg}$ of soil, which were submitted to the water replenishment level based on evapotranspiration of the crop, until reaching $80 \%$ of the field capacity, in order to guarantee the germination process and seedling development. Seeds were then sown with 07 seeds of the cultivar FMS Brilhante (from the Mato Grosso do Sul Foundation-FMS), equidistant per experimental unit, at a $2.0 \mathrm{~cm}$ depth. After the germination, about 20 days after sowing, thinning was performed, leaving one plant per experimental unit. The water content of the soil was monitored by weighing the experimental units. The irrigation of the experimental units was done manually by using irrigators.

Nitrogen fertilizations were divided, with $1 / 3$ of the doses applied at the time of planting and 2/3 applied at 30 days after sowing. Potassium and phosphate fertilizations were done before planting. After completing the crop cycle, at 75 days after sowing, the plant height was measured and then the plants were harvested, the grains were harvested manually, for later drying of the material and weighing of the mass in an electronic scale.

Table 1. Chemical and physical characteristics of the soil samples evaluated in the $0-20$ $\mathrm{cm}$ depth layer, prior to the implantation of the experiment.

\begin{tabular}{cccccccccccc}
\hline $\mathrm{pH}$ & $\mathrm{Ca}$ & $\mathrm{Mg}$ & $\mathrm{Na}$ & $\mathrm{K}$ & $\mathrm{Al}$ & $\mathrm{H}+\mathrm{Al}^{\#}$ & $\mathrm{P}$ & $\mathrm{M} . \mathrm{O}$. & Sand & Silt & Clay \\
\hline$\left(\mathrm{H}_{2} \mathrm{O}\right)$ & \multicolumn{8}{c}{$\mathrm{mmol}_{\mathrm{c}} \cdot \mathrm{kg}^{-1}$} & & $\mathrm{mg} \cdot \mathrm{dm}^{-3}$ & \multicolumn{4}{c}{${\mathrm{g} \cdot \mathrm{kg}^{-1}}$} \\
\hline 5.60 & 33.2 & 6.7 & 1.0 & 2.1 & 0.0 & 35.1 & 23.1 & 11.0 & 827.6 & 70.8 & 101.6 \\
\hline
\end{tabular}

${ }^{\#} \mathrm{H}+\mathrm{Al}$ : potential acidity. 


\subsection{Statistical Analysis}

The results of the 1000-grain weight, plant height and dry shoot biomass were submitted to the statistical analysis, using the application of statistical program $\mathrm{R}$, version 2.2.1. The $\mathrm{F}$ test was initially performed and, for cases of significance of the interaction between factors, the polynomial regression analyzes (response surface) were performed. In cases of non-significant interaction, the isolated factor effect was analyzed through regression when it had a significant effect by the $\mathrm{F}$ test. The significance level adopted in all analyzes was $5 \%$.

\section{Results and Discussion}

The $\mathrm{N}$ doses were significant for the weight of 1000 grains, for the dry shoot biomass and for the height of the crambe plants (Table 2). Potassium fertilization did not significantly influence any parameter analyzed, and the same behavior was also observed in the combinations between this nutrient and the others (nitrogen and phosphorus), as well as in the triple interaction.

Santos et al. [10], using potassium fertilization in crambe, did not observe significant differences for dry shoot biomass or 1000 grains weight, and according to these authors, the high potassium content in the soil may have influenced the variables studied. In the present study, the initial potassium content (Table 1) is considered as medium [11], which may have been responsible for the non-differentiation of potassium doses in the evaluated variables.

The highest yield corresponding to $6.01 \mathrm{~g}$, estimated by the model of regression equation that best fit the data, was obtained with the application of the doses of $0.419 \mathrm{~g}$ of $\mathrm{N}$ combined with $0.78 \mathrm{~g}$ of $\mathrm{P}_{2} \mathrm{O}_{5}$, representing the increase of $170.72 \%$, when compared to the $2.22 \mathrm{~g}$ obtained with the control treatment (Figure 1).

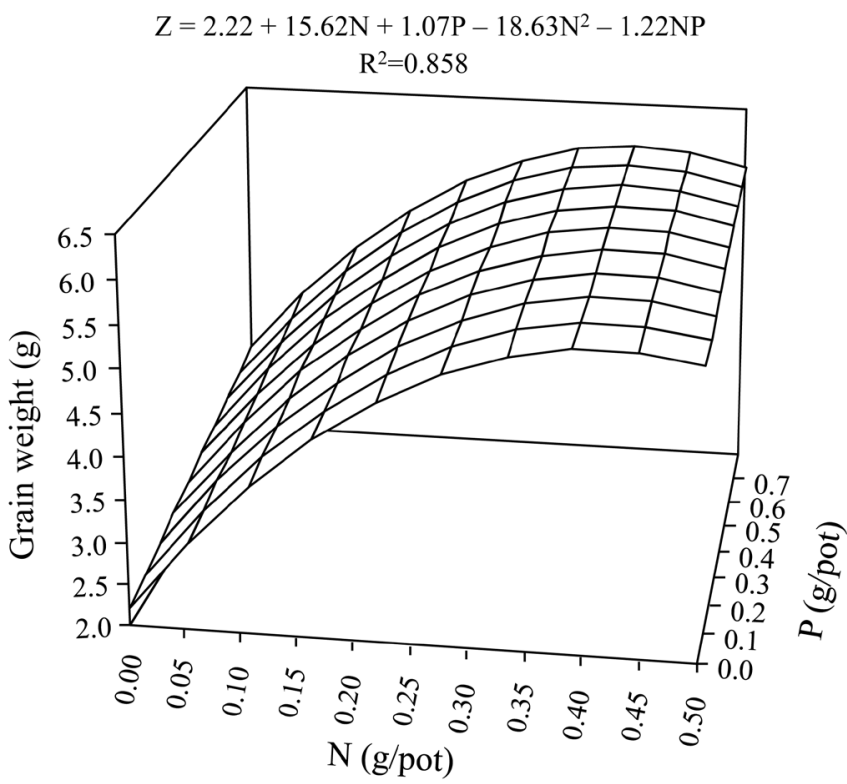

Figure 1. Weight of 1000 grains of crambe in response to nitrogen and phosphorus doses. 
A. C. F. de Vasconcelos et al.

Table 2. Statistical analysis of the variables weight of 1000 grains, shoot dry biomass and height of crambe plants as a function of the N, P and K doses in the soil.

\begin{tabular}{|c|c|c|c|c|c|}
\hline Source & D.F. & Sum of Squares & Mean Square & Stat. F & $P$-value \\
\hline \multicolumn{6}{|c|}{ Weight of 1000 grains } \\
\hline Nitrogen $(\mathrm{N})$ & 3 & 282.37 & 94.12 & 35.45 & 0.00 \\
\hline Phosphorus (P) & 3 & 19.17 & 6.39 & 2.41 & 0.07 \\
\hline Potassium (K) & 3 & 10.39 & 3.46 & 1.30 & 0.28 \\
\hline $\mathrm{N} \times \mathrm{P}$ & 9 & 36.53 & 4.06 & 1.53 & 0.14 \\
\hline $\mathrm{N} \times \mathrm{K}$ & 9 & 21.24 & 2.36 & 0.89 & 0.54 \\
\hline $\mathrm{P} \times \mathrm{K}$ & 9 & 29.04 & 3.23 & 1.22 & 0.29 \\
\hline $\mathrm{N} \times \mathrm{P} \times \mathrm{K}$ & 27 & 74.42 & 2.76 & 1.04 & 0.43 \\
\hline Residue & 125 & 331.92 & 2.66 & - & - \\
\hline CV (\%) & - & - & 35.36 & - & - \\
\hline General mean & - & - & 4.60 & - & - \\
\hline \multicolumn{6}{|c|}{ Shoot dry biomass ${ }^{+}$} \\
\hline Nitrogen $(\mathrm{N})$ & 3 & 27494.54 & 9164.85 & 65.82 & 0.00 \\
\hline Phosphorus (P) & 3 & 519.63 & 173.21 & 1.24 & 0.30 \\
\hline Potassium (K) & 3 & 176.79 & 58.93 & 0.42 & 0.74 \\
\hline $\mathrm{N} \times \mathrm{P}$ & 9 & 1902.70 & 211.41 & 1.52 & 0.15 \\
\hline $\mathrm{N} \times \mathrm{K}$ & 9 & 1031.53 & 114.61 & 0.82 & 0.60 \\
\hline $\mathrm{P} \times \mathrm{K}$ & 9 & 1020.42 & 113.38 & 0.81 & 0.60 \\
\hline $\mathrm{N} \times \mathrm{P} \times \mathrm{K}$ & 27 & 3937.94 & 145.85 & 1.05 & 0.41 \\
\hline Residue & 125 & 17405.67 & 139.25 & - & - \\
\hline CV (\%) & - & - & 24.27 & - & - \\
\hline General mean & - & - & 48.62 & - & - \\
\hline \multicolumn{6}{|c|}{ Height of plants } \\
\hline Nitrogen $(\mathrm{N})$ & 3 & 5731.43 & 1910.48 & 9.74 & 0.00 \\
\hline Linear & 1 & - & 5529.75 & 28.20 & 0.00 \\
\hline Quadratic & 1 & - & 167.76 & 0.85 & 0.35 \\
\hline Deviation & 1 & - & 87.93 & 0.44 & 0.50 \\
\hline Phosphorus (P) & 3 & 96.25 & 32.08 & 0.16 & 0.92 \\
\hline Potassium (K) & 3 & 113.78 & 37.93 & 0.19 & 0.90 \\
\hline $\mathrm{N} \times \mathrm{P}$ & 9 & 778.63 & 86.51 & 0.44 & 0.91 \\
\hline $\mathrm{N} \times \mathrm{K}$ & 9 & 1001.79 & 111.31 & 0.57 & 0.82 \\
\hline $\mathrm{P} \times \mathrm{K}$ & 9 & 949.18 & 105.46 & 0.54 & 0.84 \\
\hline $\mathrm{N} \times \mathrm{P} \times \mathrm{K}$ & 27 & 6737.44 & 249.53 & 1.27 & 0.19 \\
\hline Residue & 125 & 24703.83 & 196.06 & - & - \\
\hline CV (\%) & - & - & 13.24 & - & - \\
\hline General mean & - & - & 105.76 & - & - \\
\hline
\end{tabular}

${ }^{+}$Data transformed into $\frac{x^{1.38}-1}{1.38}$. 
Resende et al. [12] verified that the application of nitrogen as urea in cover in the crambe crop provided an increase of $7.69 \%$ in the mass of 1000 grains when compared to the treatments used as control, whose values varied between 6.04 and $6.15 \mathrm{~g}$.

Soratto et al. [3] evaluating the effect of fertilization of NPK doses on crambe cultivation obtained results for weight of 1000 grains varying between 6.8 and $9.3 \mathrm{~g}$. On the other hand, Silva et al. [13] obtained values of this variable varying between 6.3 and $7.7 \mathrm{~g}$ with the application of $\mathrm{P}$ in the sowing of crambe. These values are within the fertilization response range with NPK reported by Falasca et al. [14], which are between 6 and $10 \mathrm{~g}$ for 1000 grains of crambe.

The highest value of the dry shoot biomass verified in this study was $25.15 \mathrm{~g}$ (unprocessed data) with the application of the doses of $0.367 \mathrm{~g}$ of $\mathrm{N}$ combined with $0.78 \mathrm{~g}$ of $\mathrm{P}_{2} \mathrm{O}_{5}$ (Figure 2). This fertilization represented an increase of $79 \%$ when compared to the control treatment, whose estimated value was $14.05 \mathrm{~g}$ (unprocessed data).

With the increase of $\mathrm{N}$ doses, there was a decrease in plant height (Figure 3) probably because the initial amount of this element in the soil was sufficient for the development of the plants. Thus, the plants could develop without presenting responses to the $\mathrm{N}$ applied doses. Souza et al. [15], evaluating increasing doses of $\mathrm{N}$ ( 0 to $120 \mathrm{~kg} \cdot \mathrm{ha}^{-1}$ of $\mathrm{N}$ ) in crambe growth, observed that the height of the plants decreased as a function of these increasing doses, reaching the highest height, $120 \mathrm{~cm}$, with the $\mathrm{N}$ dose of $30 \mathrm{~kg} \cdot \mathrm{ha}^{-1}$.

Similarly, Resende et al. [12], when evaluating the effects of the application of $\mathrm{N}$ doses on covering in the morphological characteristics and crambe productivity, did not find significant differences in the height of the plants as a function of the doses of nitrogen applied.

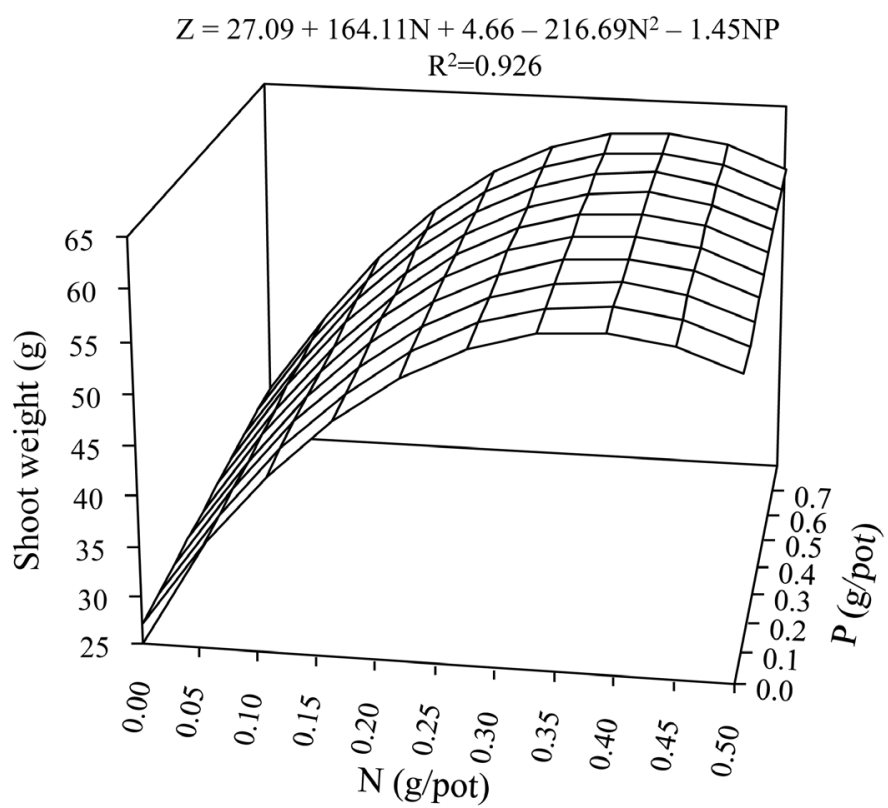

Figure 2. Shoot dry biomass of crambe in response to nitrogen and phosphorus doses. 


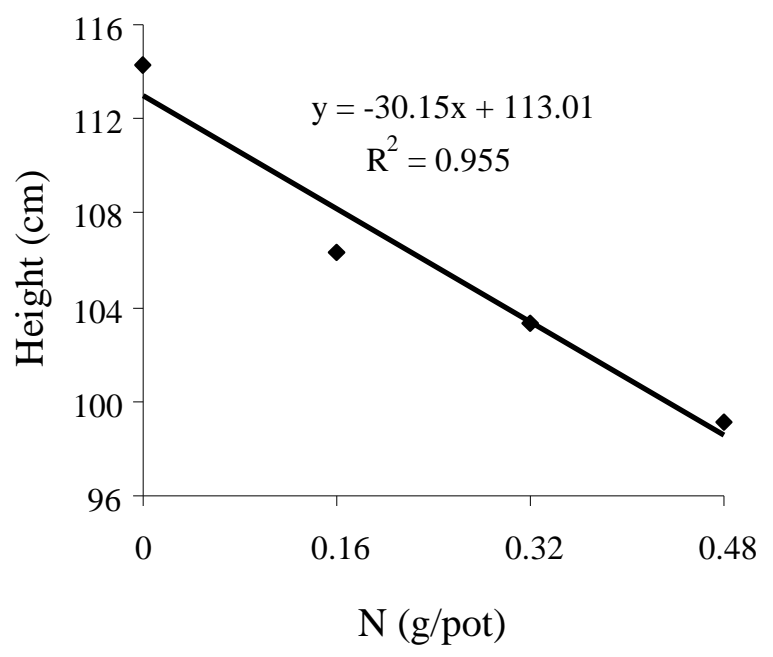

Figure 3. Plant height of crambe in response to nitrogen doses.

However, although the crop is not responsive to $\mathrm{N}$ applications for plant height, this can be considered an important factor with respect to excessive crop growth, which can trigger competition between plants, especially by light, causing a decrease in photosynthesis and, consequently, with reductions in productivity, as stated by Resende et al. [12].

Although this study does not present results that show significant differences for most of the crambe variables analyzed for the N, P and $\mathrm{K}$ doses used in the experiment, it corroborates other studies that also did not find significant responses to crambe fertilization doses.

Sousa and Chaves [16] and Chaves and Ledur [17], evaluating the effects of mineral fertilization on nitrogen and phosphorus in the growth and production of the crambe crop, state that phosphorus had no significant effect on the production of crambe, although some authors have found satisfactory answers of this nutrient in crambe [13] [18]. However, Sousa and Chaves [16] affirm that the increase in the number of grains and total dry mass were directly proportional to the increase of nitrogen doses applied.

Thus, it is observed that crambe presents great potential to develop under small doses of fertilizers with NPK. According to Freitas et al. [19], the main difficulty in recommending commercial-scale sowing of crambe for grain production is related to the lack of crop knowledge, especially the adaptability and recommendation of fertilization.

\section{Conclusions}

The height of the crambe plants was impaired as a function of increasing doses of nitrogen.

The interaction of nitrogen and phosphorus in crambe increased the number of grains and dry shoot biomass.

The growth and yield of the crop were not influenced by the use of potassium in mineral fertilization. 


\section{Acknowledgements}

To the National Council of Scientific and Technological Development (CNPq), by the research grant modality DCR for the first author.

To the Foundation for Research Support of the State of Paraíba (FAPESQ), for encouraging research.

To the Mato Grosso Foundation, for the donation of crambe seeds for this study.

\section{References}

[1] Meakin, S. and Mackey, J. (2005) Crambe (Abyssinian Mustard). Springdale Crop Sinergias Ltda, Yorkshire. http://www.ienica.net/crops/crambe.pdf

[2] Pitol, C., Broch, D.L. and Roscoe, R. (2010) Tecnologia e Produção: Crambe 2010.. Maracaju: Fundação MS. 60 p.

[3] Soratto, R.P., Sousa-Schlickg. D., Fernandes, A.M. and Souza, E.F.C. (2013) Effect of Fertilization at Sowing on Nutrition and Yield of Crambe in Second Season. Revista Brasileira de Ciência do Solo, 37, 658-666. https://doi.org/10.1590/S0100-06832013000300012

[4] Jasper, P.A., Biaggioni, M.A.M., Silva, P.R.A., Seki, A.S. and Bueno, C.O. (2010) Análise Energética da Cultura do Crambe (Crambe abyssinica Hochst) produzida em Plantio Direto. Engenharia Agrícola, 30, 395-403. https://doi.org/10.1590/S0100-69162010000300004

[5] Carlson, K.D, Gardner, J.C., Anderson, V.L. and Hanzel, J.J. (2011) Crambe: New Crop Success. In: Janick, J., Ed., Progress in New Crops, ASHS Press, Alexandria, 306-322. http://www.hort.purdue.edu/newcrop/proceedings1996/v3-306

[6] Malavolta, E. (1989) Abc da adubação. Agronômica Ceres, São Paulo, 304 p.

[7] Marschner, H. (1995) Mineral Nutrition of Higher Plants. 2nd Edition, Academic Press, London, 889 p.

[8] Gonzales, P.B. and Cihacek, L.J. (1991) Crambe Fertilization: A Literature Review. North Dakota Farm Research, 49, 17-19.

[9] Empresa Brasileira De Pesquisa Agropecuária-EMBRAPA. Centro Nacional de Pesquisa de Solos (1997) Manual de métodos de análise de solo. 2nd Edition, Rio de Janeiro, $212 \mathrm{p}$.

[10] Santos, J.I., Rogério, F., Migliavacca, R.A., Gouveia, B., Silva, T.B. and Barbosa, M.C. (2012) Efeito da adubação potássica na cultura do crambe. Bioscience Journal, 28, 346-350.

[11] van Raij, B. (Ed.) (1996) Recomendações de adubação e calagem para o Estado de São Paulo. 2nd Edition, Campinas: Instituto Agronômico. (IAC. Boletim Técnico, 100).

[12] Resende, R.K.S., Marques, R.F. and Masetto, T.E. (2015) Características morfológicas e produtividade do crambe em função da adubação nitrogenada. Revista Agrarian, 8, 279-286.

[13] Silva, T.R.B., Lavagnolli, R.R. and Nolla, A. (2011) Zinc and Phosphorus Fertilization of Crambe (Crambe abssynica Hoechst). Journal of Food Agriculture \& Environment, 9, 132-135.

[14] Falasca, S.L., Lamas, M.C., Carballo, S.M. and Anschau, A. (2010) Crambe abyssinica: An Almost Unknown Crop with a Promissory Future to Produce Biodiesel in 
Argentina. International Journal of Hydrogen Energy, 35, 5808-5812. https://doi.org/10.1016/j.ijhydene.2010.02.095

[15] Souza, L.G.M., Lazarini, E., Camargo, F.P., Bossolani, J.W. and Garcia, A. (2014) Componentes de produção e produtividade de crambe em função de doses de adubação nitrogenada em cobertura. Enciclopédia Biosfera, 10, 523-531.

[16] Sousa, R.S. and Chaves, L.H.G. (2017) Crescimento e produção do crambe submetido a doses de nitrogênio e fósforo. Revista Espacios, 38, 24.

[17] Chaves, L.H.G. and Ledur, E.O. (2014) Nitrogênio e fósforo no desenvolvimento da cultura do crambe. In: II INOVAGRI International Meeting, Fortaleza, 4196-4205. https://doi.org/10.12702/ii.inovagri.2014-a563

[18] Rogério, F., Santos, J.I., Silva, T.R.B., Migliavacca, R.A., Gouveia, B. and Barbosa, M.C. (2012) Efeito de doses de fósforo no desenvolvimento da cultura do crambe. Bioscience Journal, 28, 251-255.

[19] Freitas, M. E., Souza, L.C F., Conus, L.A., Torres, L.D., Pedrotti, M.C., Tanaka, K.S. and Makino, P.A. (2010) Teores foliares de N, P e K do crambe em função da adubação fosfatada e potássica em semeadura e nitrogênio em cobertura. In: FERTBIO-XXIX Reunião Brasileira de Fertilidade do Solo e Nutrição de Plantas. Anais, SBCS, Embrapa, CD-ROM.

Submit or recommend next manuscript to SCIRP and we will provide best service for you:

Accepting pre-submission inquiries through Email, Facebook, LinkedIn, Twitter, etc. A wide selection of journals (inclusive of 9 subjects, more than 200 journals) Providing 24-hour high-quality service User-friendly online submission system Fair and swift peer-review system Efficient typesetting and proofreading procedure Display of the result of downloads and visits, as well as the number of cited articles Maximum dissemination of your research work

Submit your manuscript at: http://papersubmission.scirp.org/

Or contact ajps@scirp.org 